\title{
PERSATUAN DAN KESATUAN BANGSA INDONESIA
}

\author{
Rachmad pandu A. E. S \\ D3 Radiologi IIK Strada indonesia \\ rachmadpandu17@gmail.com
}

\begin{abstract}
ABSTRAK
Dimasa sekarang rasa persatuan dan kesatuan dimasyarakat sangatlah kurang yang disebabkan oleh banyaknya faktor salah satunya faktor yang sangat berpengaruh adalah faktor lingkungan dan faktor wawasan yang kurang. Dengan kurangnya rasa persatuan dan kesatuan pada masyarakat sedikit demi sedikit maka bangsa Indonesia dapat terpecah belah dikarenakan saling tidak menghargai dan menghormati sesama masyarakat.
\end{abstract}

\section{Latar belakang}

Seperti yang kita ketahui persatuan dan kesatuan sangatlah penting bagi suatu negara karena jika tidak ada rasa persatuan dan kesatuan pada warga masyarakat maka suatu negara tersebut akan terjadi perpecahan yang sedikit demi sedikit akan menjadi besar. Oleh karena itu persatuan dan kesatuan merupakan hal penting yang harus dimiliki setiap negara, termasuk Indonesia. Tanpa adanya persatuan dan kesatuan, sebuah negara akan mudah terombangambing. Menurut Kamus Besar Bahasa Indonesia (KBBI) edisi keempat, persatuan adalah gabungan (ikatan, kumpulan dan sebagainya) beberapa bagian yang sudah bersatu, perserikatan, serikat. Sementara pengertian kesatuan berarti perihal satu, keesaan, sifat tunggal, satuan. Indonesia sebagai negara yang mempunyai banyak keberagaman dan perbedaan, perlu mempunyai persatuan dan kesatuan. Keberagaman yang terdapat di Indonesia, antara lain agama, suku, etnis, budaya bahasa, maupun adat istiadat .

\section{Kasus/masalah}

Di Indonesia sangat beragam suku budaya dan agama yang saling berdampingan dengan hidup rukun namun sangat disayangkan sekali sering terjadinya gesekan antar warga atau Ormas yang ada di sekitar kita yang menimbulkan perpecahan antar warga masyarakat contohnya terjadinya tawuran antar organisasi yang timbul akibat salah paham ataupun saling ejek yang terjadi sehingga timbul perselisihan. Bagaimana cara mengatasinya?

\section{Tinjauan Pustaka}

Pada hasil survey yang dilakukan pemerintah juga telah mengantisipasi perpecahan yang ada pada warga masyarakat dengan membuat peraturan yang ditujukan agar tidak adanya 
perpecahan yang terjadi seperti tawuran dll dan pihak kepolisian RI juga melakukan pengamanan pada lingkungan masyarakat agar tidak ada lagi warga masyarakat yang melakukan tawuran atau perselisihan agar masyarakat dapat hidup damai dan tentram

\section{Pembahasan}

Arti dari kesatuan dan persatuan berasal dari dua kata, yaitu:

- Persatuan

Persatuan berasal dari kata 'satu' yang berarti utuh dan tidak terpecah-belah. Arti lebih luasnya, yaitu berkumpulnya macam-macam corak dari berbagai kalangan, ras, budaya, dan adat istiadat dalam masyarakat yang bersatu dengan serasi.

- Kesatuan

Kesatuan merupakan hasil dari persatuan yang telah menjadi utuh. Hal ini dilakukan untuk terhindar dari disintegrasi, maka sangat dibutuhkan persatuan di Indonesia.

Terdapat tiga makna penting yang terkandung dalam persatuan dan kesatuan bagi bangsa Indonesia. Adapun arti dari ketiga makna persatuan dan kesatuan yang harus diketahui, antara lain:

1. Selalu menjalin rasa kepercayaan, kebersamaan, dan saling melengkapi antarbangsa demi menjaga rasa persatuan dan kesatuan bangsa.

2. Selalu berupaya untuk dapat saling menghargai satu sama lain antarsesama bangsa yang berlandaskan rasa kemanusiaan sehingga dapat tercapai kehidupan yang serasi dan harmonis.

3. Selalu menjalin rasa kekeluargaan, persahabatan, saling tolong menolong, serta nasionalisme antarbangsa yang dapat menjaga persatuan dan kesatuan bangsa.

Di dalam persatuan dan kesatuan bangsa mengandung nilai-nilai positif. Adapun nilai manfaat yang ada dalam persatuan dan kesatuan, antara lain :

4. Persatuan dan kesatuan dapat mengatasi semua perbedaan dengan penuh kesabaran dan kesadaran.

5. Persatuan antarwarga negara dapat membuat pembangunan nasional berjalan lancar, aman, baik, dan sesuai harapan.

6. Bangsa Indonesia akan lebih mudah maju dan berkembang dengan menerima perbedaan yang muncul. 
7. Akan lebih mudah untuk mencapai tujuan nasional yang tertuang dalam pembukaan UUD 1945 alinea keempat.

8. Dengan adanya persatuan dan kesatuan, akan tercipta suasana yang aman, damai, dan tenteram dalam negara. Terutama karena adanya sikap toleransi, solidaritas, dan setia kawan di antara warganya.

\section{Kesimpulan}

Disini dapat kita simpulkan bahwa persatuan dan kesatuan pada suatu negara sangatlah penting karena jika persatuan dan kesatuan tidak diterapkan suatu negara dapat terpecah belah oleh karena itu pemerintah dan pihak yang berwenang mengantisipasi kemungkinan tersebut

\section{Daftar Pustaka}

https://id-berita-yahoo-com.cdn.ampproject.org/v/s/id.berita.yahoo.com/amphtml/faktorfaktor-pendorong-persatuan-dan124015457.html?amp js $v=a 6 \& a m p$ gsa=1\&usqp=mq331AQKKAFQArABIIACAw\%3D\% 3D\#aoh=16363577798045\&referrer=https\%3A\%2F\%2Fwww.google.com\&amp tf=Dari\%2 0\%251\%24s\&ampshare=https\%3A\%2F\%2Fid.berita.yahoo.com\%2Ffaktor-faktorpendorong-persatuan-dan-124015457.html

Pengertian Persatuan dan Kesatuan, Makna, Manfaat, serta Contohnya yang Perlu Dipahami oeh Faozan Tri Nugroho pada 09 Mar 2021, 08:20 WIB Bola. Com

Sodik, M. A., Yudhana, A., \& Dwianggimawati, M. S. (2018). Nutritional status and anemia in islamic boarding school adolescent in Kediri City East Java Indonesia. Indonesian Journal of Nutritional Epidemiology and Reproductive, 1(3), 172-176.

Hidajaturrokhmah, N. Y., Nurikasari, M., Retnaningtyas, E., Siwi, R. P. Y., Sari, N., \& Sodik, M. A. (2018). Effectiveness of health education using audio visual with lectures and poster with lectures of changes in behavior selection of snacks. Indian Journal of Physiotherapy and Occupational TherapyAn International Journal, 12(4), 220-224.

Lila, R. N. M., \& Sodik, M. A. (2019). Risk Factors Of Dental Career Events In Pres School Children Ra Al-Hakim Village Damage Subscription Kesamben Blitar District. Journal of Global Research in Public Health, 4(2), 105-112. 
Sodik, M. A., \& Maulina, D. (2021). Analysis Of Android-Based Online Message Gateway Towards The Use Of Plastic Bags On PKK Mother. Journal of Global Research in Public Health, 6(1), 31-37.

Sodik, M. A., Dwianggimawati, M. S., Susanto, S. B., VerniciaHumairo, M., \& Bastian, A. (2020). The Herpes Disease Terms Of Personal Hygiene Of Student Senior High School And How To Manage This Cusses. European Journal of Molecular \& Clinical Medicine, 7(5), 969-975.

Sodik, M. A. (2014). Sikap Pencegahan Aborsi Ditinjau Dari Pengetahuan Tentang Bahaya Dan Resiko Kesehatan. Strada Jurnal Kesehatan http://publikasi. stikesstrada. ac.

id/wpcontent/uploads/2015/02/9-SIKAP-SIKAPPENCEGAHAN-ABORSI. pdf.

Sodik, M. A., \& Nzilibili, S. M. M. (2017). The Role Of Health Promotion And Family Support With Attitude Of Couples Childbearing Age In Following Family Planning Program In Health. Journal of Global Research in Public Health, 2(2), 82-89.

Siyoto, S., \& Sodik, M. A. (2015). Dasar metodologi penelitian. Literasi Media Publishing.

Sodik, M. A. (2018). Merokok \& Bahayanya.

Sodik, M. A. (2015). The "Kimcil" Phenomenon: Sexual Knowledge and Safe Sex Behaviour among Adolescents in Kediri. In The 1st Joint International Conference. 